\title{
O SINDICALISMO DE TRABALHADORES RURAIS COMO OBJETO DE DISPUTA E COMO AGENTE DE CONSTRUÇÃO DE CENTRAIS SINDICAIS NO BRASIL (2003-2017) $)^{1}$
}

\author{
Éllen Gallerani Corrêa *
}

\begin{abstract}
Durante os governos do Partido dos Trabalhadores (PT), o número de centrais sindicais cresceu no Brasil e uma acirrada competição por representatividade se estabeleceu entre elas. Este artigo tem como objetivo analisar como essa concorrência se manifestou no movimento sindical por meio do estudo de caso do sindicalismo de trabalhadores rurais, enfatizando as mudanças ocorridas na Confederação Nacional dos Trabalhadores Rurais Agricultores e Agricultoras Familiares (Contag), a principal entidade sindical desse segmento. A investigação foi realizada por meio de entrevistas com dirigentes e assessores sindicais, análise de documentos e imprensa sindical e observação de eventos de entidades selecionadas. Concluímos que a criação de novas centrais sindicais e a possibilidade de obter o seu reconhecimento legal nos anos 2000 estimularam alianças e rupturas no sindicalismo de trabalhadores rurais, as quais levaram à formação de novas entidades rurais e retroalimentaram o processo de criação de centrais.
\end{abstract}

Palavras-chave: Centrais Sindicais. Sindicalismo Rural. Trabalhadores Rurais. Movimentos Sociais do Campo. Governos do PT.

\section{INTRODUÇÃO}

As centrais sindicais são organizações nacionais que articulam e centralizam a representação sindical de trabalhadores de diferentes profissões e setores da economia. Esse tipo de organização está presente de modo ininterrupto no Brasil desde a década de 1980, período no qual o país vivenciava o processo de redemocratização e diversos movimentos populares ganharam força. Naquela conjuntura, a proposta de criar uma central sindical que unificasse nacionalmente a luta de todos os trabalhadores se fortaleceu no movimento sindical brasileiro (Rodrigues, 1991). Entretanto, em razão de divergências políticas e organizacionais entre as tendências sindicais, mais de uma central foi criada - entre elas, a Central Única dos Trabalhadores (CUT), funda-

* Instituto Federal de Educação, Ciência e Tecnologia de São Paulo (IFSP).

Rua Heitor Lacerda Guedes, 1000. Cidade Satélite Íris. Cep: 13059-581. Campinas - São Paulo - Brasil. ellen@ ifsp.edu.br

http://orcid.org/0000-0002-8430-2932

${ }^{1}$ Esse artigo é resultado da tese de doutorado intitulada Sindicalismo rural e centrais sindicais no Brasil: disputas e aproximações nas primeiras décadas do século XXI, defendida em 2018 no Programa de Pós-Graduação em Ciência Política da Universidade Estadual de Campinas (Unicamp) e realizada com apoio da Coordenação de Aperfeiçoamento de Pessoal de Nível Superior - Brasil (Capes) - Código de Financiamento 001. da em 1983 e até hoje a maior central sindical brasileira (Rodrigues, 1991).

Durante a permanência do Partido dos Trabalhadores (PT) no governo federal (20032016), especialmente nos mandatos de Lula, o espectro das centrais sindicais brasileiras vivenciou uma reconfiguração (Galvão, 2012, 2016). Um dos resultados desse rearranjo foi a expansão do número de centrais sindicais: de seis em 2003 para treze em 2016, último ano em que Ministério do Trabalho e Emprego (MTE) divulgou dados sobre o tema. Dentre os movimentos ocorridos, destaca-se a fundação de centrais sindicais na iminência e após a aprovação da Lei de Reconhecimento das Centrais Sindicais (Lei $n^{0}$ 11.648/2008), que incorpora à estrutura sindical e assegura benefícios políticos e financeiros às centrais que atingem os critérios de representatividade definidos pela Lei (Galvão, 2012, 2016; Galvão; Marcelino; Trópia, 2015).

De acordo com a literatura, o aumento do número de centrais e suas estratégias para alcançar os critérios legais de representatividade tornaram o espaço sindical mais competitivo (Cardoso, 2015; Galvão, 2012; Galvão; Marcelino; Trópia, 2015; Ladosky, 2009; Ladosky; Rodrigues, 2018). Conforme Cardoso 
(2015, p. 498), as mudanças introduzidas pela Lei estimularam "um novo processo de alinhamento do 'mercado sindical' no país”. Ao salientarem a existência de uma dinâmica concorrencial entre as centrais sindicais a partir dos anos 2000 e apontarem como ela interfere nos demais níveis do sindicalismo, tais estudos fornecem uma visão geral do fenômeno e explicam a concorrência como resultado do aumento do número de centrais.

Há, contudo, uma carência de narrativas que expliquem como a concorrência atinge setores específicos e, a partir disso, como a própria concorrência entre os setores sindicais estimulou o aumento do número de centrais. Visando contribuir com esse debate, o artigo discute como o sindicalismo de trabalhadores rurais ${ }^{2}$ se comportou nesse ambiente de concorrência e como isso se refletiu na reorganização desse setor entre os anos de 2003 e 2017. O sindicalismo de trabalhadores rurais teve uma participação importante na composição das centrais sindicais nos anos 1980, tornando-se parte constitutiva destas e vice-versa. Desde então, a interdependência entre esses dois níveis de representação foi abordada em diversos trabalhos, tais como nos de Medeiros (1989), Favareto (2006), Picolotto (2011) e Rodrigues e Ladosky (2015). Dessa forma, buscamos também dar continuidade a essa literatura, agregando novos dados empíricos e reflexões sobre as últimas duas décadas.

Nossa hipótese é de que a criação de no$\vec{\delta}$ vas centrais sindicais e a possibilidade de ob-

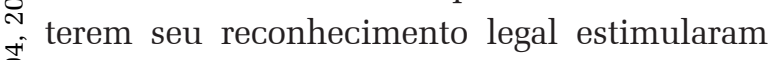
disputas e alianças no sindicalismo de trabalhađ dores rurais, as quais levaram à formação de no-

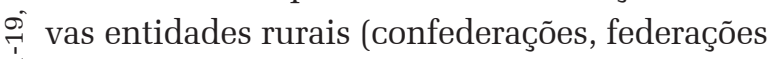
$\stackrel{2}{2}$ e sindicatos) e retroalimentaram o processo de लే criação de centrais. Para avaliá-la, mapeamos as

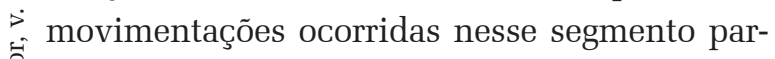
ticular e analisamos o caso de sua maior e mais

. ${ }^{2}$ Utilizamos a expressão genérica "sindicalismo de trabaI I l ludores rurais" para fazer referência às duas principais categorias que compóem esse sindicalismo no Brasil: os assalariados rurais e os agricultores de base familiar. Para uma análise da construção da identidade política dos agricultores de base familiar como trabalhadores, consultar ษ Medeiros (1989), Favareto (2006) e Picolotto (2011). antiga entidade: a Confederação Nacional dos Trabalhadores Rurais Agricultores e Agricultoras Familiares (Contag), fundada em 1963. Entre 2015 e 2018, realizamos 22 entrevistas com dirigentes das centrais sindicais ${ }^{3}$ e dirigentes e assessores da Contag, ${ }^{4}$ identificados por nomes fictícios ao longo do artigo. Também consultamos documentos e publicações dessas organizações e presenciamos, como observadores, congressos, encontros e seminários sindicais.

A pesquisa e análise de seus resultados foram orientadas pela teoria dos campos sociais de Pierre Bourdieu. ${ }^{5}$ Esse aporte teórico nos oferece subsídios para explicar o comportamento das organizações sindicais desde uma perspectiva relacional. Isto é, ao compreendê-las como integrantes de um campo, reconhecemos que não se pode definir o que são e o que defendem independentemente do que são e defendem seus concorrentes no interior do mesmo campo (Bourdieu,1989).

De acordo com Bourdieu (1989), os campos são microcosmos relativamente autônomos que possuem, dentre outros elementos, regras de funcionamento (formais e simbólicas), questões em jogo e critérios de reconhecimento próprios. Trata-se de espaços estruturados de posições, e os agentes (individuais ou coletivos) que compõem determinado campo estão permanentemente em luta para conservar ou alterar sua posição no interior dele. Nesse processo, estabelecem relações de diferentes tipos

\footnotetext{
${ }^{3}$ Foram entrevistados(as) dirigentes da Central dos Sindicatos Brasileiros (CSB), Central dos Trabalhadores e Trabalhadoras do Brasil (CTB), Central Sindical e Popular - Conlutas (CSP-Conlutas), Central Únicas dos Trabalhadores (CUT), Força Sindical (FS) e União Geral dos Trabalhadores (UGT).

${ }^{4}$ As entrevistas com os dirigentes sindicais constituíram nossa fonte privilegiada de informação, uma vez que, no decorrer da pesquisa, percebemos que o tema da relação com as centrais sindicais na Contag tendia a se circunscrever à Direção. Logo, grande parte das "questões em jogo" só pôde ser identificada nos relatos dos dirigentes e na comparação das posições das diferentes tendências internas à Confederação. A opção por esse recorte não exclui, contudo, a importância de pesquisas que investiguem como a relação do sindicalismo de trabalhadores rurais com as centrais sindicais repercute na base de sindicatos e seus associados.

${ }^{5} \mathrm{O}$ conceito de campo também é mobilizado por Rodrigues (2004), Silva (2006) e Picolotto (2011) para analisar o sindicalismo de trabalhadores rurais no Brasil.
} 
(de oposição, concordância, aliança e solidariedade) com seus pares. Logo, suas práticas e estratégias apenas podem ser compreendidas em relação à posição que ocupam no campo.

Devido às homologias existentes entre a atividade política e a sindical - como a construção de funções de representação e a separação entre leigos e profissionais - Bourdieu tratou o sindicalismo como um subcampo do campo político (Bourdieu, 1989, 2011). Dessa forma, optamos por utilizar a terminologia campo político-sindical para fazer referência ao espaço de relações formado pelas organizações sindicais brasileiras.

Além dessa introdução e das considerações finais, o artigo contém outras duas seções. Na primeira, abordamos a reconfiguração da cúpula sindical nos governos petistas. $\mathrm{Na}$ segunda, fazemos um levantamento das federações e confederações resultantes da articulação entre as centrais sindicais e vertentes do sindicalismo de trabalhadores rurais, analisamos as implicações da criação de novas entidades para a estrutura organizativa da Contag e discutimos o engajamento dessa no processo de criação de uma central.

\section{RECONGIFURAÇÃO DA CÚPULA SINDICAL NOS GOVERNOS DO PT}

A estrutura de posições do campo político-sindical brasileiro se alterou significativamente durante a permanência do PT no governo federal (2003-2016). Conforme apontaram os estudos de Galvão, os agentes sindicais de cúpula - as centrais sindicais - se reorganizaram e se diversificaram tanto do ponto de vista quantitativo quanto político-ideológico. Essa reorganização se caracterizou pela cisão de centrais sindicais formadas nos anos 1980 e 1990, fusão de correntes sindicais e formação de novas centrais (Galvão, 2012). De acordo com o MTE, existiam treze centrais sindicais no Brasil em 2016. Desse conjunto, três foram criadas anteriormente à década de 2000: CUT, Força Sindical (FS) e Central Geral dos Trabalhadores do Brasil (CGTB). Nove centrais foram fundadas durante os governos Lula e uma durante o segundo mandato de Dilma Rousseff. A Tabela 1 reúne as centrais sindicais criadas nos governos petistas.

Conforme Galvão (2012, 2016) e Galvão, Marcelino e Trópia (2015), diversos fatores motivaram a reconfiguração na cúpula sindical: a) as divergências entre as correntes sindicais no

Tabela 1 - Centrais sindicais criadas no Brasil durante os governos do PT

\begin{tabular}{|c|c|c|}
\hline CENTRAL SINDICAL & SEGMENTOS ENVOLVIDOS E MOTIVAÇÃO PRINCIPAL DA FUNDAÇÃO & ANO DE FUNDAÇÃO \\
\hline $\begin{array}{l}\text { CSP-Conlutas - Central Sindical e } \\
\text { Popular Conlutas }\end{array}$ & $\begin{array}{l}\text { Correntes sindicais que saíram da CUT por discordarem do seu apoio ao governo } \\
\text { federal }\end{array}$ & 2004 \\
\hline $\begin{array}{l}\text { NCST - Nova Central Sindical de } \\
\text { Trabalhadores }\end{array}$ & $\begin{array}{l}\text { Confederações setoriais que foram excluídas pelo governo Lula das negociações da } \\
\text { Reforma Sindical e que eram contrárias à proposta do governo e de setores sindicais de } \\
\text { promover alterações na unicidade e no imposto sindical. }\end{array}$ & 2005 \\
\hline $\begin{array}{l}\text { Intersindical - Central da Classe } \\
\text { Trabalhadora }\end{array}$ & $\begin{array}{l}\text { Correntes sindicais que saíram da CUT por discordarem do seu apoio ao governo } \\
\text { federal }\end{array}$ & 2006 \\
\hline $\begin{array}{l}\text { UST - União Sindical dos } \\
\text { Trabalhadores }\end{array}$ & $\mathrm{s} / \mathrm{i}$ & 2006 \\
\hline $\begin{array}{l}\text { UGT - União Geral dos } \\
\text { Trabalhadores }\end{array}$ & $\begin{array}{l}\text { Fusão de três antigas centrais sindicais, na iminência da aprovação da Lei no } \\
11.648 / 2008 \text {, para atender aos critérios legais de representatividade. }\end{array}$ & 2007 \\
\hline $\begin{array}{l}\text { CTB - Central dos Trabalhadores e } \\
\text { Trabalhadoras do Brasil }\end{array}$ & $\begin{array}{l}\text { Fusão de correntes sindicais egressas da CUT - por discordarem da atuação da Central } \\
\text { e porque queriam ter uma central sindical própria - com dirigentes de federações da } \\
\text { Contag, que almejavam ampliar seu capital político. A fusão ocorreu na iminência } \\
\text { da aprovação da Lei n }{ }^{\circ} 11.648 / 2008 \text { e a central formada atingiu os critérios legais de } \\
\text { representatividade. }\end{array}$ & 2007 \\
\hline $\begin{array}{l}\text { CSB - Central dos Sindicatos } \\
\text { Brasileiros }\end{array}$ & $\begin{array}{l}\text { Fusão de uma vertente sindical que rompe com a CGTB com uma central sindical } \\
\text { criada em } 2008^{*} \text { para atender aos critérios de representatividade da Lei } \mathrm{n}^{\circ} 11.648 / 2008\end{array}$ & 2012 \\
\hline PÚBLICA - Central do Servidor & $\mathrm{s} / \mathrm{i}$ & 2016 \\
\hline $\begin{array}{l}\text { CBDT - Central Brasileira } \\
\text { Democrática dos Trabalhadores }\end{array}$ & $\mathrm{s} / \mathrm{i}$ & $\mathrm{s} / \mathrm{i}$ \\
\hline $\begin{array}{l}\text { Central Unificada dos Profissionais } \\
\text { Servidores Públicos do Brasil }\end{array}$ & $\mathrm{s} / \mathrm{i}$ & $\mathrm{s} / \mathrm{i}$ \\
\hline
\end{tabular}


tocante ao conteúdo da Reforma Sindical que o governo Lula pretendia aprovar logo no seu início e à forma como as negociações foram conduzidas; ${ }^{6}$ b) o descontentamento de algumas correntes minoritárias da CUT com oapoio da Central a determinadas políticasdo primeiro governo Lula7 e com a participação desta em espaços tripartites nacionais; ${ }^{8}$ e c) a busca para atingir os critérios de representatividade definidos pela Lei de Reconhecimento das Centrais Sindicais (Lei $\mathrm{n}^{0}$ 11.648) aprovada em 2008.

De acordo com a Lei, apenas as centrais sindicais legalmente reconhecidas ${ }^{9}$ são consideradas representantes dos trabalhadores no governo federal, podendo participar de negociações em fóruns, colegiados de órgãos públicos e demais espaços de diálogo social de composição tripartite, além de terem o direito de receber $10 \%$ do imposto sindical arrecadado pelos sindicatos de base a elas filiados ${ }^{10}$ (Brasil, 2008).

${ }^{6}$ O governo Lula privilegiou as centrais sindicais como representantes dos trabalhadores nos espaços nacionais de negociação em detrimento das confederações setoriais. Estas não tiveram assento no Fórum Nacional do Trabalho (FNT), instância em que foi discutida a Reforma Sindical em 2004. Além do descontentamento com essa exclusão, as confederações setoriais se posicionaram contrariamente à realização de mudanças no princípio da unicidade e à extinção do imposto sindical que constavam na proposta de Reforma negociada no FNT (Araújo; Oliveira, 2014; Galvão, 2012). As correntes minoritárias da CUT também foram contrárias à proposta da Reforma porque, ao prever o reconhecimento legal das centrais sindicais e recursos financeiros às centrais reconhecidas, poderia levar à centralização do poder sindical nas organizações de cúpula, reduzindo o espaço de resistência das correntes minoritárias e a autonomia local dos sindicatos de base (Galvão, 2012).

${ }^{7}$ Além de se oporem à proposta de Reforma Sindical, essas correntes também se opuseram à Reforma da Previdência $\overrightarrow{7}$ aprovada em 2003 que, dentre outras medidas, estabeleసิ ceu o fim da aposentadoria integral para os servidores pú․ blicos (Araújo; Oliveira, 2014; Galvão, 2012).

சீ

\& ${ }^{8}$ Trata-se de espaços de negociação de políticas compos$\vec{\sim}$ tos por representantes do governo, empregadores e tra-

\& balhadores, os quais, na visão das correntes minoritárias

๑ da CUT, são uma forma de cooptação e de conciliação de I. classe (Galvão, 2012).

2. ${ }^{9}$ Para obter o reconhecimento legal, as centrais sindicais ; precisam comprovar anualmente o atendimento aos sem guintes critérios de representatividade: "I - filiação de,

$>$ no mínimo, 100 sindicatos distribuídos nas cinco regióes

ồ do País; II - filiação em pelo menos três regiões do País

T. de, no mínimo, 20 sindicatos em cada uma; III - filiação

\pm de sindicatos em, no mínimo, cinco setores de atividade

क econômica; IV - filiação de sindicatos que representem, 7 no mínimo, 7\% do total de empregados sindicalizados em âmbito nacional” (Brasil, 2008).

${ }^{10} \mathrm{Em}$ 2017, o governo Temer aprovou uma Reforma Trabalhista (Lei $\mathrm{n}^{0}$ 13.467) que, dentre outras medidas, tornou facultativa a contribuição dos trabalhadores para o finanUै ciamento de seus sindicatos. Essa medida revogou, por-
$\mathrm{O}$ projeto que deu origem à referida Lei foi negociado previamente com as centrais sindicais pelo MTE, uma vez que o seu reconhecimento formal e o direito de arrecadar parte do imposto sindical, pelas centrais reconhecidas, fora o único ponto da Reforma Sindical negociada no FNT sobre o qual, todos os segmentos sindicais tiveram concordância (Araújo; Oliveira, 2014; Galvão, 2012). Em decorrência, após a aprovação da Lei, as centrais existentes e diversas correntes sindicais passaram a se articular para formar centrais que atendessem aos critérios legais de representatividade.

Segundo Cardoso (2015), as mudanças no âmbito legal estimularam um aumento da filiação de sindicatos de base às centrais sindicais. Utilizando os dados do Censo Sindical do Instituto Brasileiro de Geografia e Estatística (IBGE) para 2001, último ano em que a pesquisa foi realizada, o autor mostra que, naquele momento, apenas $38 \%$ dos sindicatos se declararam filiados a uma das centrais sindicais existentes, sendo que 66\% eram filiados à CUT. Já em 2015, conforme dados do MTE, 74\% dos sindicatos ativos eram filiados a uma central, dos quais apenas 21,45\% eram filiados à CUT (Cardoso, 2015).

Das treze centrais sindicais cadastradas no MTE em 2016, apenas seis atingiam os critérios legais de representatividade e foram formalmente reconhecidas: CUT, UGT, FS, CTB, CSB e NCST. A Tabela 2 traz a evolução do índice de representatividade ${ }^{11}$ das centrais sindicais reconhecidas entre 2008 e 2016.

Os dados da Tabela 2 mostram que as duas centrais que polarizaram o campo político-sindical até os anos 2000 - CUT e FS - apresentaram queda em sua taxa de representatividade no intervalo considerado. Apesar disso, a CUT se manteve como a maior central sindical brasileira. A FS perdeu a posição de segunda maior central para a UGT em 2016 e se igualou à CTB. A CGTB apresentou crescimento entre 2008 e 2011, mas,

tanto, a obrigatoriedade da cobrança do imposto sindical que era repartido com as centrais sindicais.

${ }^{11} \mathrm{O}$ índice de representatividade é calculado dividindo-se o número de trabalhadores filiados aos sindicatos de cada central pelo número total de trabalhadores sindicalizados. 
Tabela 2 - Evolução do índice de representatividade das centrais sindicais legalmente reconhecidas entre 2008 e 2016 (\%)

\begin{tabular}{|c|c|c|c|c|c|c|c|c|c|}
\hline Central & $2008^{*}$ & 2009 & 2010 & 2011 & 2012 & 2013 & 2014 & $2015^{* *}$ & 2016 \\
\hline CUT & 35.84 & 36.79 & 38.23 & 38.32 & 36.7 & 35.6 & 34.39 & 31.73 & 30.40 \\
\hline FS & 12.33 & 13.1 & 13.71 & 14.12 & 13.7 & 13.8 & 12.59 & 10.82 & 10.08 \\
\hline UGT & 6.29 & 7.19 & 7.19 & 7.89 & 11.3 & 11.2 & 11.92 & 10.30 & 11.29 \\
\hline NCST & 6.27 & 5.47 & 6.69 & 7.04 & 8.1 & 8.1 & 8.01 & 7.65 & 7.45 \\
\hline СТВ & 5.09 & 6.12 & 7.55 & 7.77 & 9.2 & 9.2 & 9.33 & 10.36 & 10.08 \\
\hline CGTB & 5.02 & 5.02 & 5.04 & 7.02 & 3.82 & 2.98 & 2.76 & 2.55 & 1.88 \\
\hline CSB & - & - & - & - & - & - & 7.43 & 7.15 & 8.15 \\
\hline
\end{tabular}

Fonte: Alterada a partir de Lemos e Corrêa (2017, p. 11), que utilizam os dados publicados no Diário Oficial da União (DOU) e no portal do MTE na internet.

"Nos 24 meses após a publicação da Lei n ${ }^{\circ}$ 11.648/2008, o índice mínimo de representatividade exigido foi de $5 \%$

* Em 2015, foram divulgadas duas aferições no DOU: uma em janeiro e outra em abril. Os dados da tabela são da última aferição, publicada no DOU em 9 de abril de 2015.

após a saída do grupo de sindicalistas que formaria a CSB em 2012, não atingiu mais o mínimo necessário para ser reconhecida. Já a UGT, CTB, NCST e, a partir de 2014, a CSB, todas centrais sindicais criadas nos anos 2000 apresentaram crescimento do índice de representatividade.

Conforme mencionado na Introdução deste artigo, a partir da Lei $\mathrm{n}^{0} 11.648 / 2008$, estabeleceu-se, entre as centrais sindicais, uma acirrada disputa por representatividade que, na prática, significou tanto a busca por maior influência política no movimento sindical quanto pelo recebimento do imposto sindical (Cardoso, 2015; Galvão; Marcelino; Trópia, 2015; Ladosky, 2009; Ladosky; Rodrigues, 2018). Essa concorrência se manifestou na fragmentação das bases, coma criação de novas entidades por estímulo das centrais sindicais, no acirramento das disputas eleitorais para trocar de mãos as direções dos sindicatos e na investida das centrais sobre as entidades que não eram filiadas a nenhuma central (Cardoso, 2015; Ladosky, 2009).

\section{A CONCORRÊNCIA ENTRE AS CEN- TRAIS SINDICAIS DESDE O SINDICA- LISMO DE TRABALHADORES RURAIS}

Nossa pesquisa identificou quatro movimentos no sindicalismo de trabalhadores rurais relacionados à reconfiguração das centrais sindicais e à concorrência entre elas por representatividade: a) o surgimento de novos sindicatos, federações e confederações de trabalhadores rurais com o apoio de diversas centrais sindicais; b) o aumento do número de sindicatos e trabalhadores rurais filiados à central sindical; c) a dissociação sindical promovida pela Contag em sua estrutura organizativa; d) a aliança de setores da Contag com correntes sindicais que saíram da CUT para a formação de uma nova central sindical, o que culminou no reposicionamento da primeira diante das centrais sindicais.

\section{Criação de novas entidades de cúpula no sindicalismo de trabalhadores rurais}

Por meio do acompanhamento da imprensa sindical e de informações obtidas nas entrevistas, mapeamos as organizações rurais de cúpula (confederações e federações) criadas com o apoio de centrais sindicais nas décadas de 2000 e 2010. ${ }^{12}$ A Tabela 3 traz as entidades captadas pela pesquisa. Estiveram envolvidas tanto as centrais fundadas no bojo da reconfiguração descrita na seção anterior quanto aquelas que já existiam. Ou seja, antigas e novas centrais buscaram criar seu espaço próprio ou ampliar o já existente no sindicalismo de trabalhadores rurais.

No caso das novas, a única que contou com uma expressiva participação do sindicalismo de trabalhadores rurais desde a fundação foi a CTB, como mostrado na Tabela 1. As

${ }^{12}$ De acordo com a legislação sindical brasileira, são necessárias, no mínimo, três federações estaduais para a criação de uma confederação nacional. Logo, os novos sistemas confederativos identificados na pesquisa pressupõem a existência de federações que, por sua vez, precisam de, no mínimo, cinco sindicatos de base para serem criadas. 
demais centrais foram fundadas por segmentos cultura familiar existentes no país (Instituto com pouca ou nenhuma tradição de ativismo Brasileiro de Geografia e Estatística, 2009). ${ }^{14}$ entre os trabalhadores rurais, expandindo-se, Segundo relato dos dirigentes de centrais sinde fato, para essa categoria posteriormente. dicais entrevistados, a Lei $\mathrm{n}^{\mathrm{o}} 11.326 / 2006$, que

Tabela 3 - Confederações e federações de trabalhadores rurais criadas com apoio de centrais sindicais entre 2003 e 2017

\begin{tabular}{|c|c|c|c|}
\hline Entidades sindicais de trabalhadores rurais & $\begin{array}{c}\text { Categoria } \\
\text { representada }\end{array}$ & $\begin{array}{l}\text { Ano de } \\
\text { fundação }\end{array}$ & $\begin{array}{l}\text { Central } \\
\text { sindical }\end{array}$ \\
\hline $\begin{array}{l}\text { Contraf-Brasil - Confederação dos Trabalha- } \\
\text { dores na Agricultura Familiar do Brasil }\end{array}$ & $\begin{array}{l}\text { Agricultores(as) } \\
\text { familiares }\end{array}$ & $2005^{*}$ & CUT \\
\hline $\begin{array}{l}\text { Fetragro - Federação Estadual dos Trabalha- } \\
\text { dores e Empregados Rurais na Agricultura } \\
\text { do Estado de São Paulo }\end{array}$ & $\begin{array}{l}\text { Agricultores(as) } \\
\text { familiares e } \\
\text { assalariados(as) } \\
\text { rurais }\end{array}$ & 2009 & CSB \\
\hline $\begin{array}{l}\text { Conafer - Confederação Nacional dos } \\
\text { Agricultores Familiares e Empreendedores } \\
\text { Familiares Rurais }\end{array}$ & $\begin{array}{l}\text { Agricultores(as) } \\
\text { familiares }\end{array}$ & 2011 & FS \\
\hline $\begin{array}{l}\text { Confetraf Brasil - Confederação Nacional } \\
\text { dos Trabalhadores na Agricultura Familiar, } \\
\text { Federações e Sindicatos da Agricultura Fa- } \\
\text { miliar }\end{array}$ & $\begin{array}{l}\text { Agricultores(as) } \\
\text { familiares }\end{array}$ & $\begin{array}{l}\text { Filia-se à } \\
\text { UGT em } \\
2013^{* *}\end{array}$ & UGT \\
\hline $\begin{array}{l}\text { Feer-PE - Federação dos Empregados e Assa- } \\
\text { lariados Rurais de Pernambuco }\end{array}$ & $\begin{array}{l}\text { Assalariados(as) } \\
\text { rurais }\end{array}$ & 2015 & $\begin{array}{l}\text { CSP-Con- } \\
\text { lutas }\end{array}$ \\
\hline $\begin{array}{l}\text { Contar - Confederação Nacional dos Traba- } \\
\text { lhadores Assalariados e Assalariadas Rurais }\end{array}$ & $\begin{array}{l}\text { Assalariados(as) } \\
\text { rurais }\end{array}$ & 2015 & CUT e CTB \\
\hline $\begin{array}{l}\text { Conaf Brasil - Confederação Nacional da } \\
\text { Agricultura Familiar do Brasil }\end{array}$ & $\begin{array}{l}\text { Agricultores(as) } \\
\text { familiares }\end{array}$ & $\begin{array}{l}\text { Filia-se à FS } \\
\text { em 2016** }\end{array}$ & FS \\
\hline $\begin{array}{l}\text { Fedafer - Federação Democrática dos Agri- } \\
\text { cultores e Agricultoras e Empreendedores } \\
\text { Rurais de Pernambuco }\end{array}$ & $\begin{array}{l}\text { Agricultores(as) } \\
\text { familiares }\end{array}$ & 2017 & $\begin{array}{l}\text { CSP-Con- } \\
\text { lutas }\end{array}$ \\
\hline
\end{tabular}

Fonte: Elaboração própria a partir de dados da pesquisa de campo.

* Foi fundada em 2005 como Federação dos Trabalhadores na Agricultura Familiar do Brasil (Fetraf-Brasil) e transformada em confederação em 2016.

* * Não obtivemos a informação sobre a data de fundação da entidade, apenas a data de sua filiação à central sindical que apoiou sua fundação.

Como se pode observar, a maioria das novas organizações postula a representação dos agricultores(as) familiares. ${ }^{13}$ Das oito entidades criadas, cinco são dessa categoria (Conస్ traf-Brasil, Conafer, Confetraf Brasil, Conaf ㄱ Brasil, Fedafer). Com exceção da Contraf-Brasil - que foi criada a partir da região Sul e se \& expandiu para o Nordeste ao longo dos anos Iิ 2000 (Picolotto, 2018) - as demais foram cria$\dot{2}$ das a partir da região Nordeste, que concentra §ึ metade do total de estabelecimentos de agri$\vec{b}$

13 A partir de dados da Pesquisa Nacional por Amostra de Domicílios (PNAD-IBGE), Rodrigues, Ladosky e Bicev (2016) apontam que foi entre os agricultores(as) familiares - que a sindicalização rural mais cresceu nas últimas déT) cadas. Em 1992, havia aproximadamente 2,4 milhões de

o trabalhadores rurais sindicalizados no Brasil, dentre os quais $25 \%$ eram assalariados e $75 \%$ não assalariados. Já em 2014, o total de sindicalizados rurais aumentou para 3,6 milhões, dos quais apenas $16 \%$ eram assalariados e $84 \%$ eram não assalariados. definiu a agricultura familiar como categoria profissional, teria incentivado a criação de novas entidades sindicais para esse público. ${ }^{15}$ Duas entidades são de assalariados(as) rurais (Contar e Feer-PE) e uma representa ambas as categorias (Fetragro), configurando-se como uma entidade eclética.

Do universo dessas novas entidades, apenas a Fetragro (eclética) e a Contar (assalariados) são legalmente reconhecidas, ou seja, possuem registro sindical. ${ }^{16}$

14 De acordo com o Censo Agropecuário de 2006, dos 4.367.902 estabelecimentos de agricultura familiar existentes no Brasil, 2.187.295 (50\%) se encontravam no Nordeste (Instituto Brasileiro de Geografia e Estatística, 2009).

${ }^{15}$ A Lei $n^{0} 11.326 / 2006$ definiu critérios para enquadrar os produtores agrícolas na categoria agricultor familiar e empreendedor familiar rural para fins de acesso a políticas públicas, não tendo validade para fins de enquadramento sindical, o que não impediu os setores sindicais de se basear nela para fundar organizações sindicais.

${ }^{16} \mathrm{O}$ sindicalismo brasileiro, conforme determina a lei, se organiza a partir do princípio da unicidade sindical. Isso significa que apenas um único sindicato (federação ou confederação) é reconhecido pelo Estado (obtém o registro sindical) para representar legalmente dada categoria em determinada base territorial. Quando já há uma entidade reconhecida, as que são criadas posteriormente geralmente se valem da estratégia de desmembrara categoria ou base territorial existente para conseguir o registro. A Contar foi a primeira organização a solicitar a representação nacional dos assalariados(as) rurais, portanto obteve o reconhecimento legal. Já a Fetragro representa um caso inquietante, pois foi criada como uma entidade eclética em uma conjuntura em que a tendência no sindicalismo rural é o desmembramento de entidades ecléticas em específicas ou a criação, de início, de entidades específicas. Nossa hipótese é de que a Fetragro logrou obter o registro sindical porque, quando o obteve, já não havia mais entidades ecléticas no estado de São Paulo. 
Nesse quesito, se igualam a outras três entidades de cúpula do sindicalismo de trabalhadores rurais que também possuem registro: Contag, fundada em 1963; Federação dos Empregados Rurais Assalariados do Estado de São Paulo (Feraesp), fundada em 1989; Federação dos Trabalhadores e Trabalhadoras na Agricultura Familiar de Santa Catarina (Fetraf-SC/CUT), fundada na década de 2000. ${ }^{17}$

A posse do registro sindical confere às entidades sindicais a prerrogativa de negociar e celebrar acordos com o governo e, até 2017, conferia também o direito de arrecadar o imposto sindical dos trabalhadores de sua base territorial (filiados ou não). Ao contrário, as entidades que não possuem o registro sindical não desfrutam dessas prerrogativas. Entretanto isso não impede que essas organizações adquiram legitimidade perante seus associados e que essa possa se converter em reconhecimento político. Esse foi o caso da Contraf-Brasil/CUT durante o governo Lula. Mesmo sem ter o registro sindical, a Confederação integrou os principais espaços de discussão e elaboração de políticas públicas para a agricultura familiar criados no período, como mostra o estudo de Grisa (2012).

De acordo com o MTE, entre 2012 e $2016,{ }^{18}$ o número de sindicatos de trabalha- dores rurais filiados a alguma das centrais sindicais cresceu mais do que o número total de sindicatos de trabalhadores rurais com registro sindical, o que indica que as centrais lograram captar novos adeptos. O número de trabalhadores rurais associados a sindicatos filiados a alguma das centrais sindicais também aumentou. No primeiro ano da série, dos 2.128.195 trabalhadores rurais filiados a sindicatos, 54,5\% eram também filiados a alguma das centrais sindicais. Já no último ano, dos 3.165.059 trabalhadores rurais sindicalizados, 63,7\% eram também filiados a alguma das centrais sindicais (Ministério da Economia, 2016).

Em 2012, 53\% dos 2.656 sindicatos rurais existentes eram filiados a uma central sindical. Já em 2016, esse percentual sobe para pouco mais de $56 \%$, de um universo de 2.783 sindicatos, o que, considerado o curto período da série (apenas quatro anos), nos parece significativo. Contudo há ainda no setor rural um amplo espaço para disputa e crescimento das centrais sindicais (Rodrigues; Ladosky; Bicev, 2016). A distribuição entre as centrais sindicais dos sindicatos e trabalhadores rurais filiados à central pode ser observada nas Tabelas 4 e 5 , respectivamente.

Tabela 4 - Número de sindicatos de trabalhadores rurais filiados por central sindical (2012-2016)

\begin{tabular}{l|c|c|c|c|c|c|c|c|c|c}
\hline \multirow{2}{*}{ Central } & \multicolumn{2}{|c|}{$\mathbf{2 0 1 2}$} & \multicolumn{2}{c|}{$\mathbf{2 0 1 3}$} & \multicolumn{2}{c|}{2014} & \multicolumn{2}{c}{2015} & \multicolumn{2}{c}{$\mathbf{2 0 1 6}$} \\
\cline { 2 - 13 } & $\mathbf{n}^{\mathbf{0}}$ & $\mathbf{\%}$ & $\mathbf{n}^{\mathbf{0}}$ & $\mathbf{\%}$ & $\mathbf{n}^{\mathbf{0}}$ & $\mathbf{\%}$ & $\mathbf{n}^{\mathbf{0}}$ & $\mathbf{\%}$ & $\mathbf{n}^{\mathbf{0}}$ & \% \\
\hline CUT & 722 & 51,35 & 729 & 50,59 & 750 & 49,90 & 767 & 50,33 & 780 & 49,84 \\
\hline CTB & 273 & 19,42 & 316 & 21,93 & 354 & 23,55 & 371 & 24,34 & 381 & 24,35 \\
\hline FS & 178 & 12,66 & 170 & 11,80 & 163 & 10,84 & 157 & 10,30 & 150 & 9,58 \\
\hline UGT & 127 & 9,03 & 120 & 8,33 & 114 & 7,58 & 116 & 7,61 & 120 & 7,67 \\
\hline CBDT & 81 & 5,76 & 69 & 4,79 & 76 & 5,06 & 64 & 4,20 & 70 & 4,47 \\
\hline CGTB & 21 & 1,49 & 20 & 1,39 & 18 & 1,20 & 19 & 1,25 & 17 & 1,09 \\
\hline CSB & - & - & - & - & 20 & 1,33 & 21 & 1,38 & 35 & 2,24 \\
\hline CSP & 2 & 0,14 & 11 & 0,76 & - & - & - & - & - & - \\
\hline CSP-Conlutas & 1 & 0,07 & 1 & 0,07 & 1 & 0,07 & 1 & 0,07 & 2 & 0,13 \\
\hline NCST & 1 & 0,07 & 5 & 0,35 & 7 & 0,47 & 8 & 0,52 & 10 & 0,64 \\
\hline Total & 1.406 & 100 & 1.441 & 100 & 1.503 & 100 & 1.524 & 100 & 1.565 & 100 \\
\hline
\end{tabular}

Fonte: MTE. Aferição das centrais sindicais, vários anos. Elaboração própria.

${ }^{17}$ Não obtivemos a informação sobre a data exata de fundação desta organização.

No intervalo considerado, a CUT e a

${ }^{18}$ Não há dados disponíveis para anos anteriores e posteriores. CTB são as duas centrais mais representati- 
Tabela 5 - Trabalhadores rurais filiados a centrais sindicais (2012-2016)

\begin{tabular}{|c|c|c|c|c|c|c|c|c|c|c|}
\hline \multirow{2}{*}{ Central } & \multicolumn{2}{|c|}{2012} & \multicolumn{2}{|c|}{2013} & \multicolumn{2}{|c|}{2014} & \multicolumn{2}{|c|}{2015} & \multicolumn{2}{|c|}{2016} \\
\hline & $n^{0}$ & $\%$ & $\mathbf{n}^{\mathbf{o}}$ & $\%$ & $n^{\mathbf{o}}$ & $\%$ & $n^{0}$ & $\%$ & $n^{0}$ & $\%$ \\
\hline CUT & 827.577 & 71,29 & 864.667 & 57,92 & 876.349 & 58,43 & 823.314 & 54,57 & 1.095 .629 & 54,29 \\
\hline СТВ & 41.911 & 3,61 & 341.139 & 22,85 & 370.507 & 24,70 & 376.893 & 24,98 & 490.247 & 24,29 \\
\hline FS & 121.073 & 10,43 & 119.118 & 7,98 & 121.375 & 8,09 & 124.068 & 8,22 & 161.406 & 8,00 \\
\hline UGT & 83.402 & 7,18 & 81.119 & 5,43 & 43.764 & 2,92 & 47.491 & 3,15 & 58.142 & 2,88 \\
\hline CBDT & 54.568 & 4,70 & 42.523 & 2,85 & 41.753 & 2,78 & 64.132 & 4,25 & 82.155 & 4,07 \\
\hline CGTB & 31.621 & 2,72 & 31.763 & 2,13 & 27.109 & 1,81 & 27.152 & 1,80 & 27.662 & 1,37 \\
\hline CSB & - & - & - & - & 14.727 & 0,98 & 39.608 & 2,63 & 64.829 & 3,21 \\
\hline CSP & 450 & 0,04 & 9.740 & 0,65 & - & - & - & - & - & - \\
\hline CSP-Conlutas & 167 & 0,01 & 167 & 0,01 & 167 & 0,01 & 167 & 0,01 & 539 & 0,03 \\
\hline NCST & 125 & 0,01 & 2.591 & 0,17 & 4.181 & 0,28 & 5.948 & 0,39 & 37.605 & 1,86 \\
\hline Total & 1.160 .894 & 100 & 1.492 .827 & 100 & 1.499 .932 & 100 & 1.508 .773 & 100 & 2.018 .214 & 100 \\
\hline
\end{tabular}

Fonte: MTE. Aferição das centrais sindicais, vários anos. Elaboração própria.

vas entre sindicatos e trabalhadores rurais. A CUT permanece como a maior central no setor rural, mas foi perdendo espaço para a CTB, principalmente no número de trabalhadores rurais filiados. Isso indica que a desfiliação de sindicatos teve impacto significativo na representatividade da CUT entre os trabalhadores rurais. A CTB, por sua vez, cresceu entre os sindicatos e teve aumento de amplitude ainda maior entre os trabalhadores rurais. Conforme Rodrigues, Ladosky e Bicev (2016), a CUT e a CTB se assemelham no fato de a maior parcela de suas bases se localizar no Nordeste e no setor rural. Em termos absolutos, a CUT ultraసี passa a CTB, mas, em termos relativos, a CTB é N mais nordestina e rural que a CUT (Rodrigues; Ladosky; Bicev, 2016).

ชे A FS é a terceira central mais represen-

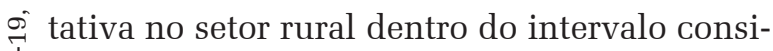
$\stackrel{2}{2}$ derado e apresentou decréscimo nas duas vari+ áveis em questão. A UGT manteve um número $\therefore$ de sindicatos filiados não muito distante ao da F⿱ trabalhadores, indicando que seus sindicatos são menos representativos do que os da FS. As demais centrais sindicais são minoritárias no setor rural, entretanto nossa pesquisa revelou que algumas delas estão engajadas na amplia- ção da sua base nesse segmento. Sobre isso, cabem alguns destaques.

No estado de São Paulo, a CSB possui a filiação da Feraesp ${ }^{19}$ e da Fetragro, ${ }^{20}$ o que configura uma situação paradoxal, já que essas duas federações concorrem entre si por filiações de sindicatos. A CSP-Conlutas esteve perto de conquistar a filiação da Feraesp em 2014, mas a aliança entre as duas organizações não se formalizou. Em seguida, a Central passou a organizar ações de luta pela terra no estado de São Paulo e na região Norte, bem como estimular a organização de entidades sindicais rurais no Nordeste. Apesar de a Feraesp estar atualmente filiada à CSB, $38 \%$ dos seus sindicatos associados eram filiados à UGT em 2017 (Corrêa, 2018), outra situação paradoxal. ${ }^{21}$

Se, por um lado, os movimentos descritos até aqui expressam, ao menos formalmen-

${ }^{19}$ Conforme dados da própria Feraesp, essa possuía 53 sindicatos filiados em 2017, totalizando 18.365 trabalhadores associados.

${ }^{20}$ De acordo com dados obtidos em entrevista, a Fetragro possuía em torno de 25 sindicatos filiados em 2017, concentrados na região de Tupã (oeste paulista) (Pedro, dirigente da CSB, 27/10/2017). Não obtivemos informações sobre o número de trabalhadores associados a esses sindicatos.

${ }^{21}$ As estratégias de inserção das diversas centrais sindicais no setor rural foram discutidas de maneira mais detalhada em trabalho anterior, assim como a tortuosa relação da Feraesp com essas organizações (Corrêa, 2018). 
te, a formação de unidades entre organizações sindicais rurais e urbanas no âmbito das centrais sindicais, por outro, indicam um processo de fragmentação da representação sindical dos trabalhadores rurais, agora pulverizada entre um número maior de sindicatos, federações e confederações. Como cada organização busca ampliar continuamente seus filiados interesse que se reforça quando está associada a uma central sindical que compartilha o mesmo objetivo -, o aumento no número de organizações acirra a concorrência interna ao sindicalismo de trabalhadores rurais. Isso afeta todos agentes inseridos no espaço de relações formado por essas entidades, os quais balizam suas estratégias, levando em consideração sua posição na correlação de forças desse espaço e as possíveis estratégias de seus concorrentes (Bourdieu, 1989, 2011).

\section{O processo de dissociação sindical na Contag}

É no quadro desse novo arranjo do sindicalismo de trabalhadores rurais que se pode compreender a deliberação da Contag de promover a dissociação sindical em sua estrutura organizativa. Ao longo de sua trajetória, a Contag defendeu de forma intransigente sua estrutura de representação eclética baseada na categoria trabalhador rural, mesmo diante dos fortes questionamentos e das pressões advindas de tendências sindicais adversárias. ${ }^{22}$ Entre 2014 e 2016, contudo, seu posicionamento sofreu uma inflexão. Amparada

${ }^{22}$ Como já retratado pela literatura, essas tendências expressavam as demandas de dirigentes de sindicatos de base e de trabalhadores assalariados e agricultores familiares pela criação de entidades sindicais específicas para esses dois segmentos, em razão das particularidades de sua inserção na esfera produtiva, condições de trabalho e reivindicações. A partir de meados dos anos 1980 até meados dos 1990, pipocaram no sindicalismo rural oposições sindicais cutistas aos sindicatos ecléticos da Contag. A Feraesp foi a primeira organização criada como consequência desse movimento "de baixo para cima" (Favareto, 2006; Medeiros, 1989; Picolotto, 2011). Logo, as dinâmicas sindicais relacionadas à reorganização das centrais analisadas nesse artigo se sobrepuseram a antigos conflitos do sindicalismo rural, contribuindo para dar lhes novos encaminhamentos, como é o caso do processo de dissociação da Contag. em resoluções do MTE, a Contag delibera por representar apenas a agricultura familiar e se engajar na criação de um sistema sindical específico para os assalariados(as) rurais, o que resultou na fundação da Contar em 2015.

De acordo com os(as) entrevistados(as), a proposta de dissociação sindical vinha sendo defendida por federações cutistas da Contag ${ }^{23}$ desde a década de 1990. No entanto, nos diversos momentos em que foi colocada para discussão, a proposta sempre fora derrotada, pois predominava entre as federações da Contag a posição de que a dissociação dividiria a base de trabalhadores rurais e enfraqueceria o movimento sindical rural.

Segundo nos relatou um dos assessores da Confederação, esse debate foi reacendido em 2009, quando a Secretaria de Relações de Trabalho (STR) do MTE concedeu registro sindical para seis Sindicatos dos Trabalhadores na Agricultura Familiar (Sintrafs), situados na região Nordeste. A concessão desses registros alterava a base sindical de mais de trinta sindicatos da Contag, retirando seu direito de representar legalmente a agricultura familiar. A Contag questionou a decisão do MTE e exigiu explicações do então ministro do trabalho, Carlos Lupi, que, em resposta, suspendeu a tramitação dos processos de pedido de registro de novos sindicatos rurais específicos (Márcio, assessor da Contag, 25/04/2017).

Em 2013, já na gestão do ministro do trabalho Manoel Dias, a SRT/MTE retomou as discussões sobre a organização sindical rural, tendo em vista as diversas decisões judiciais favoráveis à concessão de registro sindical a entidades sindicais específicas ao mesmo tempo em que continuava vigente a categoria eclética de trabalhador rural (Márcio, assessor da Contag, 25/04/2017). Para tanto, foi criado o Grupo de Trabalho Rural (GT Rural) com o objetivo de estudar e propor critérios de representatividade para as entidades sindicais rurais (Confederação Nacional dos Trabalhadores da Agricultura, 2017), do qual fizeram

${ }^{23}$ Federações da Contag que são filiadas à CUT. 
parte a Contag, Contraf-Brasil/CUT, Feraesp e as cinco centrais sindicais legalmente reconhecidas naquele momento (CUT, FS, CTB, UGT e NCST).

Por meio da sua participação no GT Rural, a Contag obteve acesso às informações do Cadastro Nacional de Entidades Sindicais (CNES), permitindo-lhe avaliar numericamente o nível de penetração em sua base de organizações sindicais concorrentes (Márcio, assessor da Contag, 25/04/2017). De acordo com o CNES, em 2013, havia 133 sindicatos rurais específicos com registro sindical deferido pelo MTE por força de decisões judiciais: 117 de assalariados(as) rurais e dezesseis de agricultores(as) familiares. Além desses, que já possuíam registro, outros 324 novos pedidos de entidades específicas, não vinculadas à Contag, aguardavam na fila para serem analisados, número que teria aumentado para seiscentos em 2014 (Confederação Nacional dos Trabalhadores na Agricultura, 2017).

O principal consenso do GT Rural foi o de que a categoria eclética trabalhador rural, especificada pelo Decreto-Lei $\mathrm{n}^{0}$ 1.166/1971, poderia ser dissociada nas categorias específicas de assalariados rurais e de agricultores familiares (Picolotto; Medeiros, 2016). Essa possibilidade foi prevista na Nota Técnica $n^{0}$ 88/2014 do Ministério do Trabalho e Previdência Social (2014). A partir de então, a dissociação do sistema Contag se inicia. Entre 2014 ন్ e o primeiro semestre de 2016, a Confederação $\underset{\sim}{*}$ orientou seus sindicatos e suas federações a optar pela representação sindical de uma das categorias e alterar seus estatutos (Confederaจे ção Nacional dos Trabalhadores na Agricultu¿. ra, 2017). Após a definição da categoria a ser में representada, aquelas entidades que optassem $\vec{*}$ pela representação dos agricultores(as) familiares deveriam se mobilizar para criar, no seu município e estado, o sindicato e a federação de assalariados(as) rurais e vice-versa.

A primeira situação foi a mais comum. Até meados de 2016, das 27 federações da Contag, 21 já haviam realizado a dissociação: dezenove optaram pela representação da agricultura familiar (RS, SC, PR, SP, ES, DF, GO, PA, RO, BA, TO, MA, PI, CE, RN, PB, PE, AL e SE) e duas pela representação dos assalariados(as) rurais (MS e RJ). As outras seis ainda não haviam se dissociado, permanecendo ecléticas (MG, MT, AC, AM, RR, AP) (Confederação Nacional dos Trabalhadores na Agricultura, 2017). Destacamos o caso da federação de MG, filiada à CTB, que foi contrária à deliberação da Contag por considerar que a decisão fere a unidade do movimento sindical de trabalhadores rurais e declarou que se manterá eclética, segundo João, dirigente da Contag, em entrevista (17/04/2017).

Em outubro de 2015, as duas federações que optaram por representar os assalariados(as) rurais (MS e RJ) e outras cinco novas (PA, PE, GO, RS e PR) se reuniram para fundar a Contar. A Feraesp se envolveu nas articulações para sua fundação, mas não se filiou. Após dois anos do início do processo de dissociação, seria a vez da própria Contag fazer sua opção. Em abril de 2016, durante a assembleia de seu Conselho Deliberativo, aprovou a alteração do seu estatuto para representar apenas os agricultores(as) familiares, passando a se chamar, sem modificar sua sigla, Confederação Nacional dos Trabalhadores Rurais Agricultores e Agricultoras Familiares (Contag) (Confederação Nacional dos Trabalhadores na Agricultura, 2017).

No Texto Base para o seu $12^{\circ}$ Congresso, realizado em 2017, a Contag explicita que a decisão de promover a dissociação foi motivada por pressões externas, advindas principalmente do Poder Judiciário, que teria firmado claro entendimento de que a categoria trabalhador rural era eclética e que a criação de entidades específicas de representação não feria a unicidade sindical (Confederação Nacional dos Trabalhadores na Agricultura, 2017).Contudo o gatilho para a produção desse entendimento pelo Judiciário foram os pedidos de registro sindical de entidades criadas com o apoio de antigas e novas centrais sindicais no ambien- 
te de concorrência descrito anteriormente. As entrevistas com os(as) dirigentes revelam a preocupação dos sindicalistas da Contag com a entrada desses novos agentes na disputa pela representação sindical dos trabalhadores rurais, conforme demonstra o trecho a seguir.

A Contag também com essa tomada de decisão dela, de fazer a dissociação dos assalariados com a agricultura familiar, também ela vem impulsionada um pouco também por essas brigas. Porque o fato do assédio de outras centrais ocupando espaço no campo e disputando esse lugar acabou deixando a gente meio que de orelha em pé nessa história [...] principalmente quando a gente começou ver Força Sindical com mais de trezentos sindicatos de assalariados criados por aí querendo registrar, registrando, querendo registrar sindicato na mesma base que tinha outros nossos trabalhando. No caso da Força Sindical mesmo era uma forma de ela ir adentrando na nossa base, porque "ah, é eclético, então estou criando um específico” [...]. Na verdade, pra alguns tem sido assim, pragmatismo, com a história inclusive do reconhecimento da central. Tipo assim, "onde é que eu posso crescer? Preciso crescer de alguma forma”. então o rural acaba sendo olhado para isso... por quê? Porque ele é eclético [...] e não é uma base pequena, né?! (Manoela, dirigente da Contag, 17/04/2017).

Constatamos, portanto, que a opção pela dissociação sindical foi a estratégia encontrada pela Contag para manter sua posição de porta-voz oficial da agricultura familiar, categoria que vinha priorizando desde meados dos anos 1990 (Favareto, 2006; Medeiros, 2014; Picolotto, 2011), diante do surgimento de novos pretendentes vinculados às antigas e novas centrais sindicais. Logo, apesar da proposta estar em debate no sindicalismo rural e dentro da própria Contag desde longa data, o acirramento da competição entre os agentes sindicais foi decisivo para que ela deliberasse pela dissociação no contexto em que o fez, sob o risco de perder a representação legal das duas categorias específicas contidas na categoria eclética de trabalhador rural.

\section{Reposicionamento da Contag diante das centrais sindicais}

A Contag esteve filiada à CUT durante catorze anos (1995-2009). Ao longo desse período, vínculos colaborativos foram construídos entre as duas organizações e ações conjuntas foram realizadas, aproximando suas agendas. Contudo as divergências com relação ao tema da unicidade sindical permaneceram. Os conflitos se acirraram quando, em 2005, sindicalistas da CUT criaram uma organização, agora em âmbito nacional, concorrente ao sistema Contag: a Federação Nacional dos Trabalhadores na Agricultura Familiar (Fetraf-Brasil/ CUT), que se transformou na Contraf-Brasil/ CUT em 2016 (Picolotto, 2018). Esse episódio descontentou, principalmente, as federações da Contag não filiadas à CUT (conhecidas como federações independentes) e a Corrente Sindical Classista (CSC), que dirige a federação da Contag na Bahia e estava na CUT desde a década de 1990.

Em 2007, as federações independentes e a CSC, duas vertentes que possuem perfil político-ideológico e trajetórias distintas, se associaram para fundar a CTB. ${ }^{24}$ A partir de então, a base de sindicatos e federações e a direção da Contag se dividiu, no que tange ao vínculo com as centrais sindicais, entre a CUT e a CTB. Em decorrência, a Contag se desfiliou formalmente da CUT em 2009.

As federações independentes e a CSC têm em comum a defesa intransigente da unicidade sindical e da contribuição sindical obrigatória, por isso ambas se sentiram atingidas pela atitude da CUT. Todavia se forjaram a partir de identidades sindicais ${ }^{25}$ diferentes. As

${ }^{24}$ A corrente Sindicalismo Socialista Brasileiro (SSB), organizada em 1997 como um braço sindical do Partido Socialista Brasileiro (PSB), também participou da criação da CTB, porém é numericamente minoritária na Central. Sua orientação político-ideológica é próxima à da CSC (Corrêa, 2018).

${ }^{25}$ Compreendemos a identidade sindical, nos termos definidos por Hyman (2001), como a construção de um pertencimento coletivo de agentes que possuem uma posição semelhante na estrutura econômica, levando-os a expressar uma determinada orientação ideológica. A identidade sindical orienta estrategicamente a atuação dos sindicatos 
federações independentes são as do RS, SC, PR (região Sul), SP, MG (região Sudeste), MS, MT (região Centro-Oeste) e PB (região Nordeste). Para caracterizar esse grupo, nos apoiamos em relatos dos(as) entrevistados(as) e na literatura, contudo as fontes não recobrem a totalidade das federações. ${ }^{26}$

Após o golpe militar de 1964, as federações independentes estiveram sob a influência de organismos ligados à ala conservadora da Igreja Católica, como a Frente Agrária Gaúcha (Picolotto, 2011), a Frente Agrária Paranaense (Silva, 2006), a Frente Agrária Paulista (Welch, 2010) e os Círculos Operários Cristãos no caso da federação de MG (Ferreira Neto, 1999 apud Zangelmi; Oliveira; Sales, 2013). ${ }^{27}$ A diretriz desses organismos era de que a organização sindical dos trabalhadores rurais fosse conduzida dentro dos limites da ordem, respeitando as regras legais vigentes e colaborando com o Estado (Picolotto, 2011), e também se orientasse para busca da harmonia entre as classes (Ricci, 1999).

Nas décadas de 1980 e 1990, essas federações foram contrárias à filiação da Contag a uma central sindical em geral e à CUT em particular. Argumentavam que o sistema Contag, dada a sua longevidade, unidade e reconhecimento político, havia se tornado "uma coisa diferenciada”, à qual não poderia se sobrepor uma central sindical. ${ }^{28}$ Eram favoráveis, portanto, à continuidade de uma concepção corporativista de organização sindical,

ao definir seus objetivos e formas de persegui-los. Isso significa que as identidades condicionam as respostas sindi-

f cais aos desafios conjunturais, mas também se adaptam a eles (Hyman, 2007).

Ðิ ${ }^{26}$ A discussão se baseia, principalmente, em dados das feक derações da região Sul e Sudeste que, por sua vez, foram

$\stackrel{\circ}{\rightarrow}$ as que defenderam de forma mais enfática uma posição

$\because$ “antiCUT" dentro da Contag nos anos 1990 e que partici-

2. param ativamente da fundação da CTB.

๗ే 27 Até meados dos anos 1990, a federação de MG foi di-

$>$ rigida por uma composição entre cutistas e independen-

ธิ tes. Porém, no final da década, esse último grupo desfez

7. a composição e ganhou as eleições sindicais, tornando-se dominante na direção (Magalhã̃es, 2008).

๘ ${ }^{28}$ A defesa dessa "especificidade dos trabalhadores ruI rais" levou uma parcela das federações independentes a

defender que a Contag se transformasse em uma "central

camponesa", reunindo não apenas entidades sindicais,

mas também movimentos sociais rurais de fora do campo

político-sindical. Essa ideia permeava a Contag desde os anos 1970 (Ricci, 1999). segundo a qual cada categoria deve reivindicar seus interesses separadamente. Nesse sentido, e diferentemente das vertentes sindicais que se inspiram na esquerda marxista, esse grupo não compartilha de uma visão de classe trabalhadora ampliada, da qual faria parte tanto os trabalhadores assalariados quanto os trabalhadores da agricultura de base familiar, mas de classe camponesa. Por conseguinte, adotar estratégias que promovam a solidariedade entre trabalhadores urbanos e rurais é considerado, no mínimo, secundário à atividade sindical.

Essas federações também têm um discurso de defesa da separação entre sindicalismo e partidos políticos, fazendo que, muitas vezes, se autodenominem e sejam identificadas por seus pares na Contag como um grupo "sem ideologia partidária”. ${ }^{29}$ Com relação à CUT, criticam seu estreito vínculo com o PT, ao qual atribuem o perfil de "confronto" da Central. Esse perfil se expressaria na prática cutista de estimular a formação de oposições para ganhar a direção de entidades do sistema Contag, expandindo não só a sua influência sobre os trabalhadores, mas também a do partido.

A CSC, por sua vez, foi fundada no final dos anos 1980 e corresponde à ala sindical do Partido Comunista do Brasil (PCdoB), que tem em seu horizonte a luta pelo socialismo. Logo, forjou sua identidade sindical a partir dos referenciais da esquerda marxista. Seus membros são conhecidos no campo político-sindical como classistas e, ao menos no plano do discurso, defendem o fim da exploração dos trabalhadores e a construção de uma sociedade socialista sem classes e desigualdades sociais.

Ao longo dos anos 1990, a CSC se tornou a segunda maior força sindical no interior da CUT (Costa, 1995), principalmente por ter sob sua influência grande número de sindicatos de trabalhadores rurais na Bahia. A Corren-

${ }^{29}$ Entretanto, essa caracterização precisa ser relativizada, pois apenas uma parte do grupo não é filiada ou próxima a algum partido político. A outra não apenas é filiada como, aliás, se candidata a cargos políticos. Ou seja, o fato de defenderem a não intervenção dos partidos nos sindicatos não significa que não tenham preferências e, inclusive, uma atuação político-partidária. 
te considera a unicidade sindical uma forma de resistir às investidas do capital para dividir os trabalhadores, pois evita a formação de milhares de sindicatos pequenos e frágeis (Borges, 2008). Por isso, quando estava na CUT, se posicionava contrariamente às propostas de pluralismo sindical oriundas de outras correntes e, portanto, à criação de entidades sindicais paralelas às legalmente reconhecidas.

Internamente à Contag, a associação entre federações independentes e CSC implicou no rompimento dessa última com as federações cutistas, alterando o equilíbrio de forças na di- reção e na base da Confederação. A Figura 1 retrata a configuração de forças na direção da Contag antes e após a fundação da CTB. Já o Mapa 1 apresenta a divisão da base de federações da Contag entre a CUT e a CTB: quinze são filiadas à CUT e nove à CTB. Apenas a Fetag-PB não é filiada a nenhuma central sindical.

A defesa em comum da unicidade sindical foi a razão manifesta pelas federações independentes e a CSC para justificar sua aliança. Contudo, como discutimos ao caracterizar as duas vertentes, a defesa da unicidade se faz por caminhos distintos em cada uma delas. Isso nos

Figura 1 - Divisão interna dos grupos que dirigem a Contag

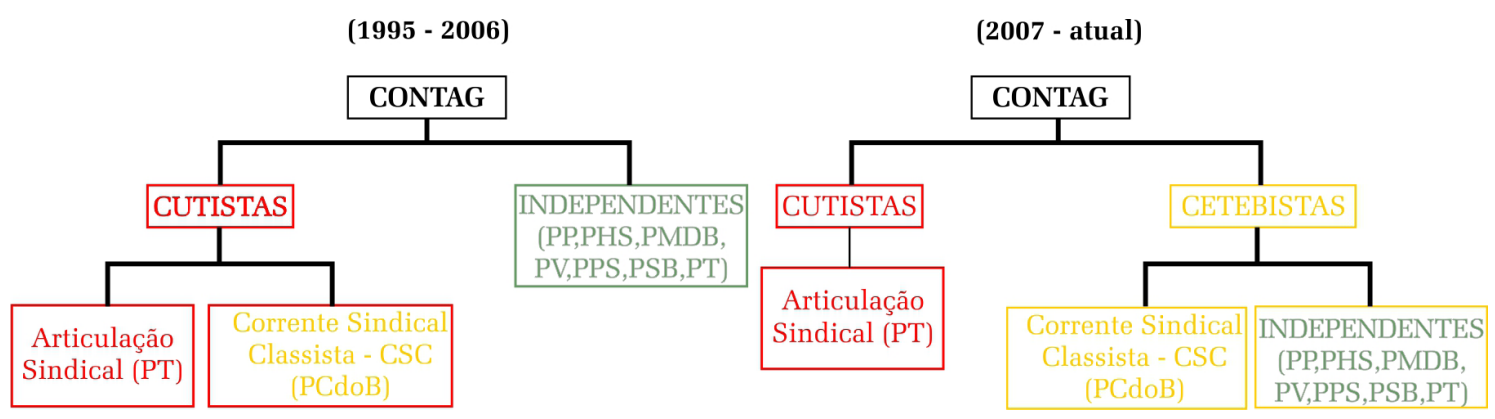

Fonte: Elaboração própria a partir de dados obtidos junto às entidades sindicais em questão

Mapa 1 - Distribuição das Federações da Contag por filiação à central sindical (2007-2017)

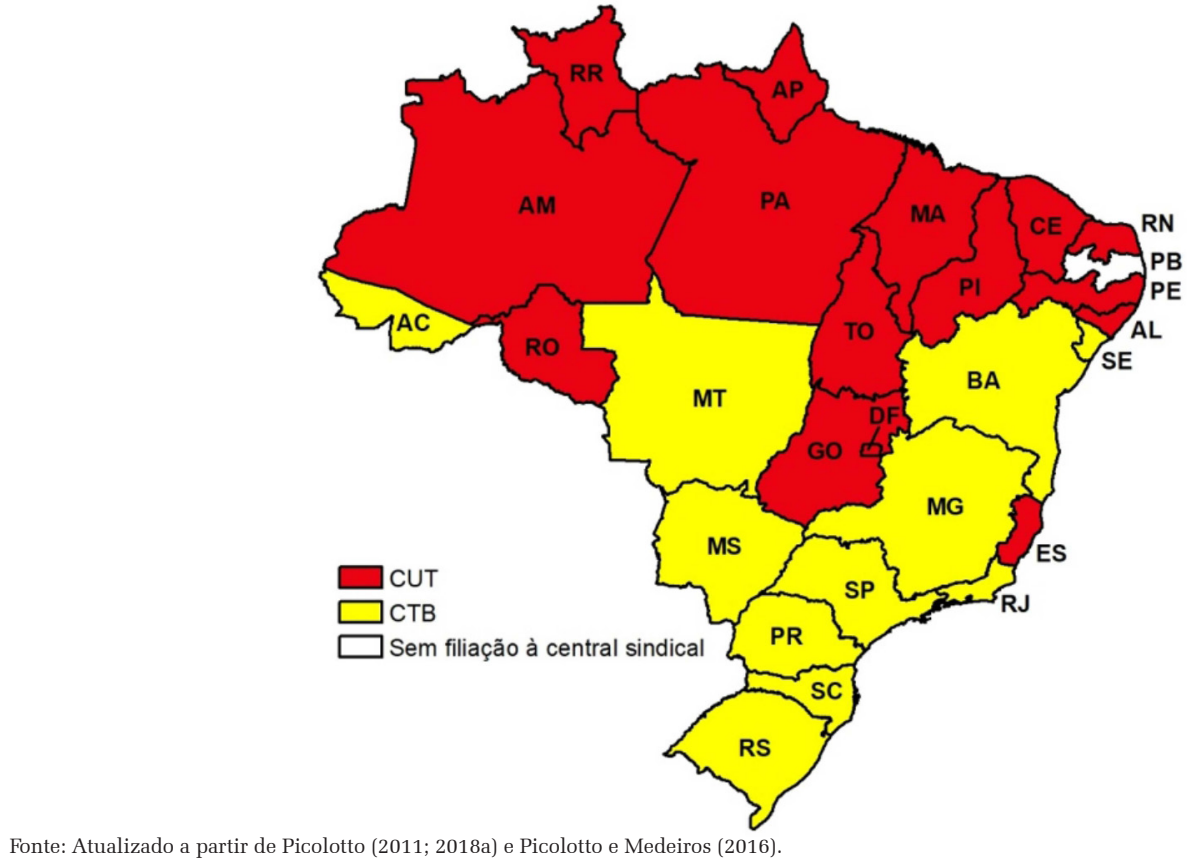


levou a averiguar a hipótese de que essa aliança representaria uma inflexão em suas trajetórias sindicais. Portanto buscar sua explicação nos perfis político-ideológico das vertentes sindicais não seria suficiente. Logo, no decorrer da pesquisa, procuramos identificar quais outros elementos contribuiriam para explicar essa aliança. Apresentaremos os resultados para os dois grupos em separado.

Vejamos, primeiramente, o caso das federações independentes. A seguir, apresentamos o trecho de uma das entrevistas realizadas com os dirigentes dessa vertente, quando perguntamos sobre as razões que os levaram a se aliar à CSC.

[...] nós tínhamos aí 10 ou 12 federações ${ }^{30}$ que não eram filiadas a nenhuma central, e começou a crescer uma ideia dentro da própria CUT, de desvinculação da CUT de algumas federações que eram já filiadas e fundar uma nova central. Bom aí que entra no protagonismo [o] pessoal, especialmente do PCdoB da Bahia, junto com algumas pessoas das federações do Rio Grande do Sul, Santa Catarina e Paraná, São Paulo, Minas Gerais, sem muita ideologia partidária ${ }_{2}$ mas entraram na lógica. Bahia querendo sair da CUT pra ter um outro protagonismo, e nós tentando... vamos dizer assim, se juntar pra fazer uma outra central que não fosse a CUT [...] e aí se junta o útil e o agradável. [...] Ou seja, nós, que não temos central, vamos ter uma central e aqueles que estavam dissidentes na CUT saíram e fundou-se basicamente a CTB em cima disso né. (Cleber, dirigente da Contag, 17/04/2017, grifos nossos).

Dois momentos da fala do entrevistado são importantes para compreendermos o posicionamento desse grupo diante das centrais sindicais. O primeiro é quando o dirigente afirma que as federações independentes estavam t tentando "se juntar para fazer uma central que - não fosse a CUT". Essa sentença indica que o

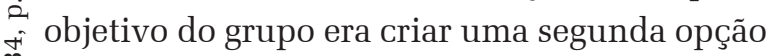
$>$ de central sindical dentro da Contag. O segundo momento relevante é quando afirma que essa segunda opção permitiria que aqueles que não tinham uma central passassem a ter.

${ }^{30}$ De acordo com o apurado na pesquisa de campo, eram sete federações que, naquele momento, não estavam filiadas a nenhuma central sindical. A federação de SP estava filiada à FS e as demais à CUT.
A argumentação já nos indica que, ao menos no momento inicial, a motivação para a criação da CTB não esteve vinculada à representação de uma determinada reivindicação, pauta ou programa político que dependesse da atuação de uma central sindical. Uma organização desse tipo seria necessária porque as federações independentes "precisavam" ter um vínculo com uma central sindical. A passagem a seguir esclarece um pouco mais o significado dessa necessidade.

[...] a partir do momento que se fundou a CTB, nós passamos a ter o mesmo respeito que nós tínhamos para com os filiados da CUT. Nós passamos a ter o mesmo respeito deles para com a gente. Porque, o que acontecia muito, a interferência da CUT, na época, aqui dentro da Contag era muito forte e, com a vinda, digamos assim, do outro campo cetebista para dentro da Contag, nós equilibramos um pouco essa questão das interferências (Cleber, dirigente da Contag, 17/04/2017, grifos nossos).

Como mostra essa outra passagem, a criação da CTB teria colocado as federações independentes em condição de igualdade com as federações cutistas. As primeiras teriam passado a ter o "mesmo respeito" que as segundas. O relato nos parece elucidativo das razões que levaram esse grupo a se organizar em uma central sindical após vinte anos de defesa da independência do sistema Contag mediante as centrais. Sua inserção na CTB não parece ter passado por uma revisão da sua posição quanto ao papel das centrais sindicais para a organização sindical dos trabalhadores rurais. Menos do que reconhecer na CTB alguma possibilidade de potencializar a luta sindical da categoria que representam, a Central é compreendida como caminho estratégico para aumentar o capital político ${ }^{31}$ do grupo internamente à Contag. Na perspectiva das federações independentes, suas posições tinham menos peso dentro da Confederação do que as das federações que estavam respaldadas por uma

${ }^{31} \mathrm{O}$ capital político é um tipo de capital simbólico, nas palavras de Bourdieu (2011, p. 204, grifo do autor): "trata-se de um capital de reputação, ligado à notoriedade, ao fato de ser conhecido e reconhecido, notável”. 
central sindical. Logo era preciso que também se equipassem com esse recurso.

Acreditamos, ainda, que a identificação do pertencimento a uma central como uma fonte de capital político também esteja relacionada à iminente aprovação da Lei $\mathrm{n}^{0} 11.648 / 2008$, que garantiria às centrais legalmente reconhecidas o status de interlocutora do Estado. Ademais, desde o início do governo Lula, quando as confederações setoriais foram excluídas das negociações do FNT, ficou evidente o papel de destaque que as centrais sindicais teriam, o que se consolidou com a aprovação da Lei (Galvão, 2012). Consequentemente, tornou-se mais atrativo para as vertentes que compõe o sistema confederativo pertencer a uma central nos anos 2000 do que o era na década anterior.

Discutamos agora o caso da CSC, que deliberou pela sua saída da CUT em 2006, manifestando as seguintes razões: a) a posição acrítica da CUT diante do primeiro governo Lula; b) a falta de democracia interna na Central; c) a defesa da CUT do pluralismo sindical (Borges, 2008; Colombi, 2018; Galvão, 2012). Por conta desses problemas, a CUT teria perdido as condições para se "colocar como polo de unidade dos trabalhadores" (Borges, 2008, p. 63), daí a necessidade de uma nova central sindical que cumprisse essa tarefa. Buscaremos argumentar que o fato de a CSC ter proposto a criação de uma central sindical às vésperas da aprovação da Lei $\mathrm{n}^{\circ}$ 11.648/2008 sugere que a possibilidade de criar uma estrutura alternativa de poder, na qual a Corrente tivesse maior protagonismo, pesou sobre a decisão de criar a CTB (Galvão, 2012). Esse argumento se reforça quando consideramos que, para criá-la, a CSC se aliou às federações independentes da Contag.

Em 2004, alguns anos antes de propor a fundação da CTB, a CSC havia criticado a criação da CSP-Conlutas por correntes que romperam com a CUT, pois isso fragmentava e fragilizava a luta dos trabalhadores contra o capital (Galvão, 2012). Todavia, ao fundar a CTB, a CSC acabou admitindo a divisão na cúpula do movimento sindical. Como justificativa, argumentou que a CUT havia perdido sua capacidade se unificar o movimento sindical devido, principalmente, a sua postura acrítica diante do governo Lula. Contudo o "alinhamento" da CUT ao governo federal, conforme pondera Galvão (2012), não era mais uma novidade em 2007. Logo, é plausível indagar por que a desfiliação desse grupo da CUT não teria ocorrido antes.

Por fim, cabe problematizar a aliança da CSC com as federações independentes sendo que a primeira, conforme seu próprio discurso, mantinha em seu horizonte a expectativa de criar uma central sindical mais combativa e democrática do que a CUT naquele momento. Os independentes representam a ala da Contag que mais se afasta dos referenciais da esquerda marxista a partir dos quais a CSC se formou. Alguns elementos bastante criticados ou secundarizados pelos independentes e atribuídos aos cutistas são também atributos da CSC: o estreito vínculo entre movimento sindical e partidos políticos (de esquerda), a adoção de métodos de luta combativos e a defesa da unidade da "classe trabalhadora".

Desse modo, o objetivo de construir uma central sindical de acordo com o perfil manifestado pelos representantes da CSC parece ter sido secundarizado diante do intento de atender aos critérios de representatividade da Lei $\mathrm{n}^{\circ}$ 11.648/2008. Cabe salientar que 40\% dos sindicatos filiados à CTB, em 2016, pertenciam ao sistema Contag. Assim, melhorar a posição no campo político-sindical - ao dirigir uma central reconhecida e com prerrogativas distintivas - nos parece ter sido um elemento relevante para a iniciativa da CSC de construir uma entidade com uma composição ideológica heterogênea, como é a CTB.

Conforme Bourdieu (1989, 2011), determinadas posições assumidas pelos grupos no campo em que atuam não podem ser explicadas unicamente com referência à sua orientação política, construída na relação com seus representados, mas devem ser analisadas no contexto das relações de força daquele campo e em relação à posição nele ocupada pelo grupo. Isso sig- 
nifica que a associação entre os independentes da Contag e sindicalistas de tradição comunista para a criação de uma central sindical pode parecer contraditória quando explicada do ponto de vista de suas posições históricas, porém adquire sentido quando relacionadas ao seu objetivo de lhes tornar mais favorável o equilíbrio de forças interno à Contag ou no campo político-sindical, respectivamente.

A partir de 2015, o Brasil passou a vivenciar uma crise política e econômica que levou ao impeachment de Dilma Rousseff. Inaugurou-se uma conjuntura adversa para os trabalhadores e suas organizações sindicais, atingidos pelo aumento do desemprego, redução do orçamento de políticas públicas e reformas na legislação trabalhista e previdenciária, que resultaram em perda de direitos (Marcelino; Galvão 2020). Nesse cenário, as centrais perderam parte de sua capacidade de financiamento, com a extinção do imposto sindical, e capital político. Se no ciclo petista foram alçadas à condição de interlocutoras privilegiadas do governo federal, no governo de Michel Temer e no atual governo de Jair Bolsonaro foram praticamente alijadas das discussões de temas do interesse dos trabalhadores. Consequentemente, a Lei $n^{0} 11.648 / 2008$, apesar de não ter sido revogada, perdeu efeitos práticos.

\section{CONSIDERAÇÕES FINAIS}

Durante a permanência do PT no governo federal, o campo político-sindical brasileiro vivenciou um processo de reorganização que $\stackrel{7}{7}$ afetou todos os níveis de representação dos $\dot{2}$ trabalhadores. As divergências internas na if CUT quanto ao apoio ao governo, o lugar pri$\vec{i}$ vilegiado que este concedeu às centrais sindicais e a aprovação, em 2008, de uma legislação que possibilitou o reconhecimento legal destas (com todos os benefícios decorrentes) contribuíram para desencadear essa reorganização, cuja dimensão mais evidente foi a multiplicação do número de centrais sindicais.
}

A situação de pluralismo sindical na cúpula, já que podiam ser legalmente reconhecidas todas as centrais que atingissem os critérios de representatividade, instalou uma dinâmica concorrencial entre elas. Deu-se início a uma corrida pelo aumento do número de sindicatos filiados por meio da disputa de direções (via eleições) dos sindicatos já existentes e/ou criação de novos sindicatos/federações/confederações. Esses passaram a pleitear o registro sindical, ameaçando o direito de representação de entidades até então reconhecidas. Neste artigo, refletimos sobre como essa dinâmica se manifestou no sindicalismo de trabalhadores rurais - um segmento que é parte constitutiva da vida das centrais sindicais desde os anos 1980 - e como este se comportou em meio a ela.

Nossa análise nos permite concluir que o sindicalismo de trabalhadores rurais foi, ao mesmo tempo, objeto e agente na disputa entre as centrais sindicais por representatividade. Foi objeto porque a maioria das centrais sindicais que buscaram atrair filiações no setor rural a partir dos anos 2000 tiveram pouca ou nenhuma participação deste setor no momento de sua fundação. E foi agente tanto porque participou ativamente da criação de uma central sindical - a CTB -, contribuindo com a reconfiguração da cúpula, quanto porque, ao ser atraído para a esfera das centrais, seus diversos segmentos atuaram na criação de novas entidades rurais, promovendo, por sua vez, a própria reoganização desse setor particular. Ou seja, o sindicalismo rural também se orientou estrategicamente nesse novo cenário do campo político-sindical.

Uma das dimensões da sua reorganização foi o aumento do número de sindicatos e trabalhadores rurais filiados à central sindical, o que pode levar a uma maior penetração de lideranças rurais e da agenda do sindicalismo rural na cúpula. Pode também estimular nesse setor uma visão menos corporativista de ação sindical ao proporcionar sua articulação com outros setores no âmbito das centrais. Essas possibilidades, se concretizadas, apontam para 
o fortalecimento da organização e mobilização dos trabalhadores rurais. A fragmentação destes, agora pulverizados entre um número maior de diferentes sindicatos, federações e confederações, aponta para a direção contrária.

A análise da trajetória da Contag também é exemplar para percebemos a reorganização do sindicalismo de trabalhadores rurais no período em questão. Desde o surgimento da CUT e das oposições sindicais, a Confederação era pressionada a se engajar na dissociação da categoria trabalhador rural. A partir dos anos 2000, se sobrepôs a esse histórico a ameaça dos novos sistemas sindicais, subsidiados pelasdiferentes centrais, de retirararem o direito de representação legal do sistema Contag, o que o levou a promover a dissociação. Esse fato mexeu profundamente com a estrutura de posições do sindicalismo rural. Dentre as consequências, destaca-sea separação da representação nacional de agricultores(as) familiares e assalariados(as) rurais.

As estratégias de determinados segmentos da Contag também produziram efeitos no nível das centrais quando esses se aliaram à CSC para criar a CTB. Esse fato nos levou a investigar os significados que pertencer a uma central sindical havia assumido para esses segmentos até então avessos à participação em centrais. Argumentamos que estar em uma central sindical, independentemente do seu perfil político-ideológico, tornou-se um meio para acessarmos benefícios assegurados pela Lei $\mathrm{n}^{\mathrm{O}} 11.648 / 2008$ - como assento nos espações nacionais e recursos materiais -, mas também para acumularem capital político e melhorar ou preservar posições dentro da própria Contag. Ou seja, "ter uma central sindical" se tornou algo a que os agentes sindicais passaram a atribuir valor, tornando-se um atributo de distinção.

Como esses novos pertencimentos construídos à margem da afinidade político-ideológica e no bojo da concorrência entre as centrais sindicais - contribuirão (ou criarão resistências) para que o sindicalismo de traba- lhadores rurais avance em suas pautas em um cenário de crise política, econômica e, a partir de 2020, também sanitária, é uma das frentes abertas por nossa investigação que pode ser explorada em esforços futuros de pesquisa.

Recebido para publicação em 09 de novembro de 2020 Aceito em 09 de abril de 2021

\section{REFERÊNCIAS}

ARAÚJO, Â. M. C.; OLIVEIRA, R. V. D. O sindicalismo na era Lula: entre paradoxos e novas perspectivas. In: OLIVEIRA, R. V. D. D.; BRIDI, M. A.; FERRAZ, M. (org.). O sindicalismo na era Lula: paradoxos, perspectivas e olhares. Belo Horizonte: Fino Traço, 2014. p. 29-59.

BORGES, A. Sindicalismo, resistência e alternativas. São Paulo: Anita Garibaldi e Coleção Vermelho, 2008.

BOURDIEU, P. O poder simbólico. Rio de Janeiro: Bertrand Brasil, 1989.

O campo político. Revista Brasileira de Ciência

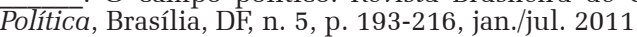

BRASIL. Lei $n^{\mathbf{0}} 11.648$, de 31 de março de 2008. Dispõe sobre o reconhecimento formal das centrais sindicais. Brasília, DF, 2008. Disponível em: http://www.planalto.gov. br/CCivil_03/Ato2007-2010/2008/Lei/L11648.htm. Acesso em: 4 dez. $2 \overline{0} 17$.

CARDOSO, A. M. Dimensões da crise do sindicalismo brasileiro. Caderno CRH, Salvador, v. 28, n. 75, p. 493-510, 2015

COLOMBI, A. P. F. A institucionalização do consenso: atuação da CUT e da FS nos governos do PT (2003-2014). 2018. Tese (Doutorado em Desenvolvimento Econômico) - Universidade Estadual de Campinas, Campinas, 2018.

CONFEDERACẼO NACIONAL DOS TRABALHADORES NA AGRICULTURA. Texto Base do $12^{\circ}$ Congresso Nacional dos Trabalhadores Rurais Agricultores e Agricultoras Familiares. Rio de Janeiro, 2017. Disponível em: http:// www.enfoc.org.br/system/arquivos/documentos/112/ texto_base_do_12_congresso_nacional.pdf. Acesso em: 28 abr. 2021 .

CORRÊA, É. G. Sindicalismo rural e centrais sindicais no Brasil: disputas e aproximações nas primeiras décadas do século XXI. 2018. Tese (Doutorado em Ciência Política) Universidade Estadual de Campinas, Campinas, 2018.

COSTA, S. Tendências e centrais sindicais. Goiânia: Editora da Universidade Católica de Goiás, 1995.

FAVARETO, A. Agricultores, trabalhadores: os trinta anos do novo sindicalismo rural no Brasil. Revista Brasileira de Ciências Sociais, São Paulo, v. 21, n. 62, 2006.

GALVÃO, A. A reconfiguração do movimento sindical nos governos Lula. In: BOITO JUNIOR, A.; GALVÃO, A. (org.). Política e classes sociais no Brasil nos anos 2000. São Paulo: Alameda, 2012.

Political action of the Brazilian labour movement: issues and contradictions facing PT governments. Studies in Political Economy, Abingdon, v. 96, p. 1-15, 2016. 
GALVÃO, A.; MARCELINO, P.; TRÓPIA, P. V. As bases sociais das novas centrais sindicais brasileiras. Curitiba: Appris, 2015.

GRISA, C. Políticas públicas para a agricultura familiar no Brasil: produção e institucionalização das ideias. 2012. Tese (Doutorado em Ciências Sociais) -Universidade Federal Rural do Rio de Janeiro, Seropédica, 2012.

HYMAN, R. Understanding European Trade Unionism. Between market, class and society. Thousand Oaks: Sage, 2001.

How can trade unions act strategically? Transfer: European Review of Labour and Research, Thousand Oaks, v. 13, n. 2, p. 193-210, 2007.

INSTITUTO BRASILEIRO DE GEOGRAFIA E ESTATÍSTICA. Censo Agropecuário 2006 - agricultura familiar: primeiros resultados. Rio de Janeiro: IBGE, 2009.

LADOSKY, M. H. G. A CUT no governo Lula: da defesa da "liberdade e autonomia" à reforma sindical inconclusa. 2009. Tese (Doutorado em Sociologia) -Universidade de São Paulo, São Paulo, 2009.

LADOSKY, M. H. G.; RODRIGUES, I. J. A CUT e o sindicalismo brasileiro nos anos recentes: limites e possibilidade, Tempo Social, São Paulo, v. 30, n. 1, p. 5376, 2018.

LEMOS, P. R. Entre o mercado e a sociedade: o sindicalismo da União Geral dos Trabalhadores (UGT). 2014. Dissertação (Mestrado em Ciência Política) -Universidade Estadual de Campinas, Campinas, 2014.

LEMOS, P. R.; CORRÊA, E. G. As estratégias das novas centrais sindicais e o debate sobre a revitalização do sindicalismo brasileiro. Crítica e Sociedade: Revista de Cultura Política, Uberlândia, v. 7, n. 2, p. 110-145, 2017.

MAGALHÃES, M. S. Trajetórias em movimentos: a construção da identidade política na organização das mulheres trabalhadoras Rurais em Minas Gerais. 2008. Tese (Doutorado em Psicologia) - Universidade Federal de Minas Gerais, Belo Horizonte, 2008.

MARCELINO, P.; GALVÃO, A. O sindicalismo brasileiro frente à ofensiva neoliberal restauradora. Tempo Social, São Paulo, v. 32, p. 157-182, 2020.

MEDEIROS, L. S. História dos movimentos sociais no campo. Rio de Janeiro: Fase, 1989.

O sindicalismo rural nas últimas décadas: mudanças e permanências. In: OLIVEIRA, R. V. D.; BRIDI, M. A.; FERRAZ, M. (org.). O sindicalismo na era Lula: paradoxos, perspectivas e olhares. Belo Horizonte: Fino Traço, 2014. p. 247-282.
MINISTÉRIO DO TRABALHO E PREVIDÊNCIA SOCIAL. Manual de Procedimentos de Registro Sindical. Brasília, DF, 2014.

MINISTÉRIO DA ECONOMIA. Consulta de Aferição das Centrais Sindicais. Brasília, DF, 2016. Disponível em: https://www.gov.br/trabalho/pt-br/assuntos/sindicatos/ consulta-de-afericao-das-centrais. Acesso em: 17 nov. 2018.

PICOLOTTO, E. L. As mãos que alimentam a nação: agricultura familiar, sindicalismo e política. 2011. Tese (Doutorado em Ciências Sociais) - Universidade Federal Rural do Rio de Janeiro, Seropédica, 2011.

Pluralismo, neocorporativismo e o sindicalismo dos agricultores familiares no Brasil. Sociedade e Estado, Brasília, DF, v. 33, p. 85-115, 2018.

PICOLOTTO, E. L.; MEDEIROS, L. S. A representação política no sindicalismo rural: antigos e novos agentes. In: ENCONTRO ANUAL DA ANPOCS, 40., 2016, Caxambu. Anais [...]. Caxambu: [s. n.], 2016.

RICCI, R. Terra de ninguém: representação sindical rural no Brasil. Campinas: Editora da Unicamp, 1999.

RODRIGUES, A. S. A Federação dos Trabalhadores na Agricultura Familiar: um novo sindicalismo em construção. 2004. Dissertação (Mestrado em Sociologia) Universidade Federal do Paraná, Curitiba, 2004. Disponível em: https://acervodigital.ufpr.br/handle/1884/2994. Acesso em: 10 ago. 2016

RODRIGUES, L. M. As tendências políticas na formação das centrais sindicais. In: BOITO JUNIOR, A. (org.). $O$ sindicalismo brasileiro nos anos 80. Rio de Janeiro: Paz e Terra, 1991. p. 13-42.

RODRIGUES, I. J.; LADOSKY, M. H. G. Paradoxo do sindicalismo brasileiro: a CUT e os trabalhadores rurais. Lua Nova, São Paulo, v. 95, p. 87-142, 2015.

RODRIGUES, I. J.; LADOSKY, M. H. G.; BICEV, J. T. Sindicalizacão e representatividade das centrais sindicais no Brasil. Trabajo y Sociedad, Santigo del Estero, n. 27, p. 43-62, 2016.

SILVA, O. H. A foice e a cruz: comunistas e católicos na história do sindicalismo dos trabalhadores rurais do Paraná. Curitiba: Rosa de Bassi, 2006.

WELCH, C. A. A semente foi plantada: as raízes paulistas do movimento sindical camponês no Brasil. São Paulo: Expressão Popular, 2010.

ZANGELMI, A. J.; OLIVEIRA, F. R. C.; SALES, I. F. O. $\mathrm{Da}$ Sindicalização às ocupações: luta pela terra em Minas Gerais (1940-1980). Revista de Ciências Humanas, Florianópolis, v. 47, n. 2, p. 306-330, 2013. 


\section{RURAL WORKERS' UNIONISM AS AN OBJECT OF DISPUTE AND AS AN AGENT FOR THE CREATION OF UNION FEDERATIONS IN BRAZIL (2003-2017)}

\author{
Éllen Gallerani Corrêa
}

During the Worker's Party (Partido dos Trabalhadores - PT) governments the number of union federations grew in Brazil, establishing a fierce competition for representation between them. This article analyzes how this competition manifested in the labor movement by the case study of rural workers' unionism, emphasizing the changes that occurred in the Confederação Nacional dos Trabalhadores Rurais Agricultores e Agricultoras Familiares (Contag), the main union entity in this segment. The study comprised interviews with union leaders and advisors, analysis of documents and union press and observation of events from selected entities. We conclude that the creation of new federations and the possibility of obtaining their legal recognition in the 2000s promoted alliances and ruptures in rural workers' unionism, leading to the formation of new rural entities and fed back into the process of creating union federations.

\section{LE SYNDICALISME DES TRAVAILLEURS RURAUX COMME OBJET DE DISPUTE ET COMME AGENT DE CONSTRUCTION DES CENTRALES SYNDICALES AU BRÉSIL (2003-2017)}

\author{
Éllen Gallerani Corrêa
}

Sous les gouvernements du Parti des travailleurs (Partido dos Trabalhadores - PT), le nombre de centrales syndicales a augmenté au Brésil et une concurrence féroce pour la représentation s'est établie entre elles. Cet article analyse comment cette concurrence s'est manifestée dans le mouvement syndical à travers une étude de cas du syndicalisme des travailleurs ruraux, en soulignant les changements survenus au sein de la Confederação Nacional dos Trabalhadores Rurais Agricultores e Agricultoras Familiares (Contag), la principale entité syndicale de ce segment. La recherche a été menée par le biais d'entretiens avec des dirigeants et des conseillers syndicaux, d'une analyse de documents et de la presse syndicale et de l'observation des événements des entités sélectionnées. On conclut que la création de nouvelles centrales syndicales et la possibilité d'obtenir leur reconnaissance légale dans les années 2000 ont stimulé les alliances et les ruptures dans le syndicalisme des travailleurs ruraux, ce qui a conduit à la formation de nouvelles entités rurales et a alimenté « en retour » le processus de création de centrales.

Keywords: Union Federations. Rural Unionism. Mots-cLÉs: Centrales Syndicales. Syndicalisme Rural Workers. Rural Social Movements. PT Rural. Travailleurs Ruraux. Mouvements Sociaux Governments.
Ruraux. Gouvernement du PT.

Ellen Gallerani Corrêa -Doutora em Ciência Política pela Universidade Estadual de Campinas (Unicamp). Professora do Instituto Federal de Educação, Ciência e Tecnologia de São Paulo (IFSP). Integrante do Grupo de Pesquisa Trabalho, Reformas Neoliberais, Movimentos Sindicais e Sociais da Unicamp e do Núcleo de Estudos em Agroecologia, Educação e Sociedade (Neaes) do IFSP, desenvolvendo pesquisas na área de trabalho rural, sindicalismo de assalariados rurais e da agricultura familiar, reforma trabalhista, movimentos sociais do campo, políticas públicas e agroecologia. Suas mais recentes publicações são "As estratégias das novas centrais sindicais e o debate sobre a revitalização do sindicalismo brasileiro" (Crítica e Sociedade, v. 7, n. 2, 2017) e "Ofensiva patronal e vulnerabilidade laboral: os efeitos iniciais da reforma trabalhista a partir do relato de empresários e sindicalistas da indústria de confecção paulista" (Política \& Trabalho, n. 53, jun./dez. 2020). 
